\title{
Achievement of cardiovascular risk factor targets in young adults with diabetes mellitus
}

This article was published in the following Dove Press journal:

Diabetes, Metabolic Syndrome and Obesity:Targets and Therapy

14 November 2010

Number of times this article has been viewed

\section{Peter J Donovan \\ $\mathrm{H}$ David Mclntyre}

Department of Endocrinology, Mater Health Services, Mater Clinical School, The University of Queensland School of Medicine, South Brisbane, QLD, Australia
Correspondence: H David Mclntyre Department of Endocrinology, Mater Health Services, Mater Clinical School, The University of Queensland School of Medicine, Raymond Terrace, South Brisbane, QLD 4I0I, Australia

Tel +6I 731636358

Email david.mcintyre@mater.org.au
Background: Many patients with diabetes mellitus fail to achieve treatment targets recommended in recognized guidelines. Little data is available in this area relating to young adults.

Objective: To assess whether treatment goals for glycosylated hemoglobin $\left(\mathrm{HbA}_{1 \mathrm{c}}\right)$, blood pressure, lipid-lowering, and process outcomes for microvascular screening are being achieved in young adults with diabetes mellitus.

Methods: A retrospective clinical record audit of 202 consecutive patients with type 1 and type 2 diabetes, aged predominantly 18-45 years, attending a specialist diabetes center in Brisbane, Australia, was conducted. Assessment was made as to whether goals for $\mathrm{HbA}_{1}$, blood pressure, lipid lowering, and microvascular screening were being achieved. Descriptive statistics and comparison of continuous variables were produced.

Results: Mean (SD) $\mathrm{HbA}_{1 \mathrm{c}}$ was $8.30 \%( \pm 1.5)$ with no statistical difference between patients with type 1 and type 2 diabetes $(P=0.44)$. Sixteen percent of patients ( $12 \%$ type $1,31 \%$ type 2$)$ had an $\mathrm{HbA}_{1 \mathrm{c}}$ of $<7 \%$. Eighty-three percent of patients had blood pressure $\leq 130 / 80 \mathrm{mmHg}$. Sixteen percent of patients with type 1 and $37 \%$ with type 2 diabetes were achieving combined lipid targets. Only $34 \%$ and $9 \%$ of patients who had an indication (and no documented contraindication) for lipid-lowering and antiplatelet therapy, respectively, were prescribed such agents. There was a significant difference in achievement of macrovascular treatment targets in patients with type 1 and type 2 diabetes, but no difference in screening or treatment outcomes in microvascular disease. Patients below the age of 25 years were less likely to achieve macrovascular treatment targets.

Conclusion: A large number of young adult patients with diabetes mellitus do not achieve recognized treatment targets. There appears to be less emphasis placed on macrovascular risk factor targets compared with previous audits in older patients, in patients with type 1 diabetes compared with type 2 diabetes and in patients younger than 25 years.

Keywords: diabetes mellitus, complications, vascular risk, hypertension, cholesterol, glycated hemoglobin

\section{Introduction}

It is well established that intensive glycemic control with both type 1 and type 2 diabetes decreases microvascular diabetic complications. ${ }^{1-3}$ Aggressive treatment of other cardiovascular risk factors including hypertension ${ }^{4,5}$ and dyslipidemia ${ }^{6,7}$ is effective in decreasing cardiovascular risk. Although aspirin may be less effective in some diabetic patients in preventing cardiovascular events, ${ }^{8}$ it is still recommended. ${ }^{9}$

The outcomes of the Bogalusa Heart and The Pathobiological Determinants of Atherosclerosis in Youth (PDAY) studies have established that overt cardiovascular disease in adults has its origins in youth, with the presence of multiple cardiovascular risk factors imparting greater risk. ${ }^{10,11}$ The only randomized studies in this age group involve 
patients with familial hypercholesterolemia, ${ }^{12}$ and it appears unlikely that other long-term studies will be conducted. Nonetheless, it has been suggested that aggressive risk factor modification in young people is justifiable and may in fact prevent, as opposed to merely decreasing the risk of, clinically overt cardiovascular disease. ${ }^{13}$ Because type $1^{14,15}$ and type 2 diabetes $^{16}$ are independent risk factors for pre- and early atherosclerotic lesions in this age group, the justification for early and aggressive intervention is likely to be stronger in patients with diabetes mellitus.

Despite all that is known about the effectiveness of intervention in people with diabetes and many widely publicized guidelines, ${ }^{9,17,18}$ multiple audits of diabetic care have demonstrated that a large proportion of patients are not achieving recommended treatment targets for $\mathrm{HbA}_{1 \mathrm{c}}$, lipid profile, and blood pressure control. ${ }^{19-24}$ Other than a large audit of German patients with type 1 diabetes, ${ }^{22}$ there is little data on the achievement of treatment targets and cardiovascular risk factor modification in younger patients with diabetes.

\section{Methods}

This retrospective cohort audit study was performed to further elucidate the proportion of young adults with diabetes mellitus achieving treatment targets. The audit cohort sample included adults with diabetes mellitus attending a specialist diabetes clinic, specifically for young adult patients (primarily aged between 18 and 45 years) at the Mater Hospital, Brisbane, Australia. This multidisciplinary clinic includes endocrinologists and training registrars, credentialed diabetes educators, dieticians, and psychologists. The clinic is attended by patients with both type 1 and type 2 diabetes. Data were collected for all patients who attended the clinic between September 2007 and March 2008. Patients were excluded if they had been followed up in the clinic for $<6$ months (most patients were followed up every three months and therefore had at least two clinic reviews), in order to ensure that patients had received appropriate specialist intervention before inclusion in analysis. If patients had attended more than once during the period of the audit, data from the most recent attendance were used primarily. For data that are not necessarily required at each visit, for example, lipid profile or urine protein studies, the record was searched to ensure that it was checked within the appropriate screening period.

The primary outcome measures examined included the adequacy of glycemic control, cardiovascular risk factor control (blood pressure and lipid targets, smoking cessation), as well as the appropriateness of microvascular complication screening and treatment. Secondary aims were to identify any differences between patients with type 1 and type 2 diabetes and patients younger or older than 25 years.

The Mater Health Services Human Research Ethics Committee (HREC) assessed this study to be a quality assurance activity exempt from HREC review in accordance with National Health and Medical Research Council (NHMRC) guidelines. All patient data were nonidentifiable. There are no conflicts of interest.

Results were compared primarily against American Diabetes Association (ADA) treatment targets, screening and treatment recommendations for 2007, which were the most recent authoritative guidelines available at the time of the review (see Table 1). ${ }^{9}$

Data are presented as mean (standard deviation). Comparisons of continuous variables between groups were by one-way analysis of variance (ANOVA). Categorical variables were analyzed using $\chi^{2}$ and Fisher's exact tests as appropriate. Significance was accepted at the $5 \%$ level on two-tailed testing for all analyses. Statistica V 8.0 (StatSoft, Tulsa, OK, USA) was used for all analyses.

\section{Results}

In total, 249 patients were available for analysis among whom 47 were excluded as they had been attending the clinic for $<6$ months. Of the 202 included patients, $111(55 \%)$ were female. The average age was $31.9( \pm 9.9)$ years. The majority of patients had type 1 diabetes mellitus (154, 76\%). Forty-two patients (21\%) had type 2 diabetes, with six diagnosed with other forms of diabetes (eg, genetic diabetes syndromes). We did not have access to data regarding patient ethnicity, though we noted that only $4 / 202$ patients $(2 \%$, all type 2 diabetes) identified themselves as indigenous Australians.

Mean $\mathrm{HbA}_{1 \mathrm{c}}$ was $8.30 \%( \pm 1.5)$ with no statistical difference between patients with type 1 and type 2 diabetes $(P=0.44)$. Only $16 \%$ of patients ( $12 \%$ type $1,31 \%$ type 2) had an $\mathrm{HbA}_{1 \mathrm{c}}$ of $<7 \%$.

Eighty-seven percent of patients had their blood pressure checked at the visit used for this report. In total, 146 patients of $176(83 \%$ ) had blood pressure $<130 / 80 \mathrm{mmHg}$ with $95 \%$ having blood pressure measurements $\leq 140 / 90 \mathrm{mmHg}$. Only $75(37 \%)$ had had their lipid profile checked and documented appropriately. Of those patients, $16 \%$ of patients 
Table I Process and outcome parameters assessed based upon American Diabetes Association guidelines

\begin{tabular}{|c|c|}
\hline Parameter & Treatment target assessed \\
\hline $\mathrm{HbA}_{\mathrm{lc}}$ & $<7 \%$ \\
\hline \multirow[t]{2}{*}{ Blood pressure } & Recorded at every visit \\
\hline & $<130 / 80 \mathrm{mmHg}$ \\
\hline \multirow[t]{7}{*}{ Dyslipidemia } & In individuals without overt cardiovascular disease \\
\hline & • LDL $\leq 2.6 \mathrm{mmol} / \mathrm{L}$ \\
\hline & $\begin{array}{l}\text { - For those aged over } 40 \text { years, statin therapy to achieve an LDL reduction of } 30 \%-40 \% \text { regardless of baseline LDL } \\
\text { levels is recommended }\end{array}$ \\
\hline & - For those younger than 40 years, but at increased risk due to other cardiovascular risk factors who do not achieve \\
\hline & lipid goals with lifestyle modifications alone, the addition of pharmacological therapy is appropriate \\
\hline & In individuals with overt CVD \\
\hline & $\begin{array}{l}\text { - Statin therapy where not otherwise contraindicated triglycerides } 1.7 \mathrm{mmol} / \mathrm{L} \text { and raise } \mathrm{HDL} \text { cholesterol } \\
\text { to }>1.0 \mathrm{mmol} / \mathrm{L} \text { in men and }>1.3 \mathrm{mmol} / \mathrm{L} \text { in women }\end{array}$ \\
\hline \multirow[t]{4}{*}{ Antiplatelet therapy } & Secondary prevention in diabetic individuals with history of CVD \\
\hline & Primary prevention strategy in those with type I or type 2 diabetes at increased cardiovascular risk, including \\
\hline & those who are older than 40 years or who have additional risk factors (family history of cardiovascular disease, \\
\hline & hypertension, smoking, dyslipidemia, or albuminuria) \\
\hline \multirow[t]{2}{*}{ Nephropathy } & Annual screening for microalbuminuria \\
\hline & Appropriate treatment with angiotensin-converting enzyme inhibitor or angiotensin 2 receptor blocker \\
\hline Retinopathy & Screening at least every 2 years \\
\hline \multirow[t]{2}{*}{ Neuropathy } & Annual screening for distal symmetric polyneuropathy \\
\hline & Screening for autonomic neuropathy with symptoms and signs annually \\
\hline \multirow[t]{2}{*}{ Smoking } & Documentation about smoking habits \\
\hline & Advice given about cessation (if appropriate) \\
\hline
\end{tabular}

Abbreviations: CVD, cardiovascular disease; HDL, high-density lipoprotein; LDL, low-density lipoprotein.

with type 1 and $37 \%$ with type 2 diabetes were achieving lipid targets, but in total, only $6.5 \%$ and $24 \%$, respectively, of the total cohort had been clearly documented as reaching these targets. Of the patients who had an indication (and no documented contraindication) for lipid-lowering therapy, 34\% (23 of 67) were prescribed such agents. In 121 patients $(60 \%)$, it was unclear whether the patient was a current smoker. In the 22 patients who were identified as smokers, 9 were given smoking cessation advice. Only 6 out of the $96(9 \%)$ patients with an indication (and no contraindication) for antiplatelet therapy were actually prescribed this therapy.

Sixty-five percent of patients had been screened for microalbuminuria. Of the 20 patients with known nephropathy, 15 had been prescribed an angiotensin-converting enzyme (ACE) inhibitor or angiotensin II receptor blocker (ARB) (two had contraindications). Thirty-four patients had retinopathy (22 nonproliferative, 8 proliferative, and 4 severity not known). Seventy-three percent of those without retinopathy had been appropriately screened within the past 2 years. Few patients had known peripheral neuropathy (9\%). Ninety-four percent of patients had been screened for this in the past year, but only very few (9\%) had been questioned regarding symptoms of autonomic neuropathy.
Tables 2 and 3 show the difference in demographics, glycemic control, and cardiovascular risk factor modification between patients with type 1 and type 2 diabetes. Tables 4 and 5 outline the differences in treatment outcomes for patients with type 1 diabetes mellitus, comparing those younger or older than 25 years to those aged 25 years.

\section{Discussion}

Despite the overwhelming evidence that improving glycemic control and cardiovascular risk factor modification improves

Table 2 Demographics and glycemic control in patients with type I and type 2 diabetes

\begin{tabular}{llll}
\hline & Type I DM & Type 2 DM & $\boldsymbol{P}$ \\
\hline Number of patients & 154 & 42 & \\
Weight (mean \pm SD) $(\mathrm{kg})$ & $78.7 \pm 17.9$ & $93.6 \pm 27.2$ & $<0.00$ I \\
$\begin{array}{l}\text { Age (mean } \pm \text { SD) } \\
\text { (years) }\end{array}$ & $29.5 \pm 16.1$ & $39.6 \pm 8.0$ & $<0.00$ I \\
Gender (\% males) & 48 & & \\
HbA $_{\text {Ic }}$ (mean \pm SD) $(\%)$ & $8.33 \pm 1.35$ & $8.13 \pm 2.01$ & 0.44 \\
$\begin{array}{l}\text { Achieving HbA } \\
\text { (ratio and } \% \text { ) }\end{array}$ & $19 / 154(12)$ & $13 / 42(3 \mathrm{I})$ & $<0.00 \mathrm{I}$ \\
\hline
\end{tabular}

Abbreviations: DM, diabetes mellitus; $\mathrm{HbA}_{\mathrm{Ic}}$, glycosylated hemoglobin; SD, standard deviation. 
Table 3 Comparison of treatment and outcome measures in patients with type I and type 2 diabetes

\begin{tabular}{|c|c|c|c|}
\hline & $\begin{array}{l}\text { Type I DM } \\
\text { Number (\%) }\end{array}$ & $\begin{array}{l}\text { Type } 2 \text { DM } \\
\text { Number (\%) }\end{array}$ & $P$ \\
\hline \multicolumn{4}{|c|}{ Macrovascular risk factor modification targets } \\
\hline \multicolumn{4}{|l|}{ Process measures } \\
\hline Blood pressure documented & $131 / 154(85)$ & $40 / 42(95)$ & 0.372 \\
\hline Lipid profile documented & 44/I54 (29) & $27 / 42(64)$ & $<0.001$ \\
\hline Antiplatelet therapy indication & $62 / 154(40)$ & $31 / 42(74)$ & $<0.001$ \\
\hline $\begin{array}{l}\text { Appropriate prescription } \\
\text { of antiplatelet therapy }\end{array}$ & $3 / 62(4.8)$ & $6 / 34(18)$ & $<0.001$ \\
\hline $\begin{array}{l}\text { Indication for lipid-lowering } \\
\text { therapy }\end{array}$ & $40 / 154(26)$ & $27 / 42(64)$ & $<0.001$ \\
\hline $\begin{array}{l}\text { Appropriate prescription of } \\
\text { lipid-lowering therapy }\end{array}$ & $12 / 40(30)$ & $\mathrm{II} / 27(4 \mathrm{I})$ & $<0.001$ \\
\hline \multicolumn{4}{|l|}{ Outcome measures } \\
\hline $\begin{array}{l}\text { Target blood } \\
\text { pressure }<130 / 80\end{array}$ & $80 /|3|(6 \mid)$ & $18 / 40(45)$ & 0.210 \\
\hline Blood pressure $\leq 140 / 90$ & $|24 /| 3 \mid(95)$ & $39 / 40(98)$ & 0.505 \\
\hline $\begin{array}{l}\text { Combined lipids target } \\
(\mathrm{LDL}<2.6 \mathrm{mmol} / \mathrm{L}, \\
\mathrm{HDL}>1.0 \mathrm{mmol} / \mathrm{L}, \\
\text { triglycerides }<1.7 \mathrm{mmol} / \mathrm{L})\end{array}$ & $7 / 44(16)$ & $10 / 27(28)$ & 0.066 \\
\hline $\mathrm{LDL}<2.6 \mathrm{mmol} / \mathrm{L}$ & $15 / 33(45)$ & $13 / 26(50)$ & 0.508 \\
\hline \multicolumn{4}{|c|}{ Microvascular complication and screening } \\
\hline $\begin{array}{l}\text { Patients screened for } \\
\text { nephropathy }\end{array}$ & $86 / 139(62)$ & $24 / 37(65)$ & 0.889 \\
\hline Patients with nephropathy & I5/I54 (9.7) & $5 / 42(12)$ & 0.831 \\
\hline $\begin{array}{l}\text { ACE inhibitor/AR2B prescribed } \\
\text { for microalbuminuria/ } \\
\text { nephropathy }\end{array}$ & II/I5 (73) & $4 / 5(80)$ & 0.422 \\
\hline $\begin{array}{l}\text { Patients screened for } \\
\text { retinopathy }\end{array}$ & $96 / 127(76)$ & 25/35 (7I) & 0.104 \\
\hline $\begin{array}{l}\text { Patients with known } \\
\text { retinopathy }\end{array}$ & $27 / 154(18)$ & $7 / 42(17)$ & 0.104 \\
\hline $\begin{array}{l}\text { Patients with peripheral } \\
\text { neuropathy }\end{array}$ & $10 / 154(6.5)$ & $8 / 42(19)$ & 0.040 \\
\hline $\begin{array}{l}\text { Screened for peripheral } \\
\text { neuropathy }\end{array}$ & I35//54 (88) & $32 / 42(76)$ & 0.041 \\
\hline
\end{tabular}

Abbreviations: ACE, angiotensin-converting enzyme; AR2B, angiotensin 2 receptor blocker; DM, diabetes mellitus; HDL, high-density lipoprotein; LDL, low-density lipoprotein.

outcomes for patients with type 1 and type 2 diabetes, most patients do not achieve recommended treatment targets. The results of our study are similar to recent audits of diabetes care outcomes in both a primary care setting 23,24 and specialist endocrinology clinics ${ }^{20}$ in Australia. Our study adds to the literature by describing attainment of glycemic and cardiovascular risk factor modification targets in a young adult population. Most previous studies have involved much older patient groups than our study (mean age 58.3-64.4 years compared with $31.9 \pm$ 9.9 years). ${ }^{20,23-25}$ This audit attempts to address this deficit in knowledge.
Table 4 Comparison of demographics and treatment outcomes in patients younger or older than 25 years

\begin{tabular}{|c|c|c|c|}
\hline & $\begin{array}{l}\text { Age } \leq 25 \\
\text { years }\end{array}$ & $\begin{array}{l}\text { Age }>25 \\
\text { years }\end{array}$ & $P$ \\
\hline Age at time of visit (years) & $21.6 \pm 2.0$ & $36.0 \pm 7.8$ & $<0.001$ \\
\hline Weight $(\mathrm{kg})$ & $77.6 \pm 14.9$ & $79.6 \pm 20.0$ & 0.015 \\
\hline $\mathrm{HbA}_{\mathrm{Ic}}(\%)$ & $8.60 \pm 1.56$ & $8.13 \pm 1.14$ & 0.007 \\
\hline Blood pressure systolic ( $\mathrm{mmHg}$ ) & $113.2 \pm 15.2$ & $118.4 \pm 16.9$ & 0.424 \\
\hline Blood pressure diastolic $(\mathrm{mmHg})$ & $67.7 \pm 10.0$ & $73.3 \pm 10.0$ & 0.987 \\
\hline LDL (mmol/L) & $2.60 \pm 0.88$ & $2.80 \pm 0.87$ & 0.938 \\
\hline $\mathrm{HDL}(\mathrm{mmol} / \mathrm{L})$ & $1.70 \pm 1.04$ & $1.41 \pm 0.33$ & $<0.001$ \\
\hline Triglycerides (mmol/L) & $1.79 \pm 1.68$ & $1.28 \pm 0.69$ & $<0.001$ \\
\hline
\end{tabular}

Notes: Data are presented as mean standard \pm deviation. $P$ values measured by unpaired $t$-test.

Abbreviations: $\mathrm{HbA}_{\mathrm{Ic}}$, glycosylated hemoglobin; $\mathrm{HDL}$, high-density lipoprotein; LDL, low-density lipoprotein.

\section{Glycemic control}

The glycemic targets in the current study were achieved by a similar percentage of patients (12\% type $1,31 \%$ type $2)$ to those in the previous audit of a specialist clinic (13\% type $1,30 \%$ type 2$).{ }^{20}$ More patients $(46 \%-52 \%)$ were achieving an $\mathrm{HbA}_{1 \mathrm{c}}<7 \%$ in the primary care setting (type 2 only). ${ }^{23,24}$ This is most likely explained by referral bias, with poor glycemic control being a frequent indication for specialist referral. However, these results and those of previous audits outline the inadequacy of our current treatments and approaches to diabetic management at both a primary care and specialist level. Tight glycemic control in older patients with type 2 diabetes and established ath-

Table 5 Comparison of macrovascular risk factor modification in patients younger or older than 25 years

\begin{tabular}{|c|c|c|c|}
\hline & $\begin{array}{l}\text { Age } \leq 25 \text { years } \\
\text { Number (\%) }\end{array}$ & $\begin{array}{l}\text { Age }>25 \\
\text { Number (\%) }\end{array}$ & $P$ \\
\hline \multicolumn{4}{|l|}{ Process measures } \\
\hline $\begin{array}{l}\text { Indication for lipid- } \\
\text { lowering therapy }\end{array}$ & $10 / 70(14.3)$ & $57 / 132(43.1)$ & $<0.001$ \\
\hline $\begin{array}{l}\text { Appropriate } \\
\text { prescription of lipid- } \\
\text { lowering therapy }\end{array}$ & $1 / 10(10)$ & $22 / 52(42.3)$ & $<0.001$ \\
\hline $\begin{array}{l}\text { Indication for } \\
\text { antiplatelet therapy }\end{array}$ & I8/69 (26.1) & $78 / 132(59.1)$ & $<0.001$ \\
\hline $\begin{array}{l}\text { Appropriate } \\
\text { prescription of } \\
\text { antiplatelet therapy }\end{array}$ & $0 / 18(0)$ & $9 / 71(12.7)$ & $<0.001$ \\
\hline Current smoker & $6 / 26(23.1)$ & I6/55 (29.1) & 0.620 \\
\hline $\begin{array}{l}\text { Appropriate smoking } \\
\text { cessation advice given }\end{array}$ & $0 / 26(0)$ & $9 / 17$ (52.9) & 0.017 \\
\hline Outcome measures & & & \\
\hline $\begin{array}{l}\text { Combined blood } \\
\text { pressure targets }\end{array}$ & $43 / 70(61.5)$ & $58 / 132(44.0)$ & 0.026 \\
\hline Combined lipid targets & $3 / 67(4.5)$ & $17 / 132(12.9)$ & 0.080 \\
\hline
\end{tabular}


erosclerosis appears to be associated with an increased rate of macrovascular events. ${ }^{26-28}$ However, in the younger cohorts of the United Kingdom Prospective Diabetes Study (UKPDS) ${ }^{29}$ and Diabetes Control and Complications Trial/ Epidemiology of Diabetes Interventions and Complications (DCCT/EDIC) 3 trials, tighter glycemic control conferred a benefit. Given this, aiming for tighter glycemic control in young patients and establishing the metabolic legacy early in the course of the disease, prior to the development of clinically overt cardiovascular disease, should be the focus. ${ }^{29,30}$

\section{Hypertension}

Hypertension is more prevalent in patients with diabetes compared with the general population. ${ }^{31}$ In this audit, a much larger proportion of patients (83\%) had recorded blood pressure measurements in the target range compared with most other studies $(26 \%-28 \%))^{19,23}$ This is not surprising given that the populations of these studies were older and exclusively had type 2 diabetes, both of which will increase the prevalence of hypertension. Our audit cohort compares favorably with a report of similarly aged patients with type 1 diabetes from the United States, ${ }^{31}$ of whom only $42 \%$ were achieving blood pressure targets. Our results are comparable to a large German audit of patients with type 1 diabetes (ranging in age from $0.25-26$ years), ${ }^{22}$ in which $89 \%-97 \%$ of patients achieved blood pressure targets. However, of the $8.1 \%$ of patients with diagnosed hypertension in that study, only $0.4 \%$ were taking antihypertensive agents. Overall, these studies demonstrate that hypertension is less prevalent in younger age groups and is probably being treated more effectively than in older patients with type 2 diabetes. Nonetheless, almost $20 \%$ of young adults with diabetes in our audit still have inadequately treated hypertension.

\section{Lipids}

Younger patients with type 2 diabetes have less favorable lipid profiles than older patients. ${ }^{32}$ Despite this and its undoubted association with cardiovascular disease, dyslipidemia appears to be less than optimally treated in this young adult population with only a minority of patients having their lipid profiles fully documented within the past 2 years. A much smaller percentage (4.5\% type 1, 24\% type 2 ) were documented to be target or below for LDL, HDL, and triglycerides. Of some reassurance, of those patients with a documented LDL, a much larger proportion (47\%) had values less than the ADA target of $2.6 \mathrm{mmol} / \mathrm{L}$. This apparent lack of attention to dyslipidemia management seems concordant with the German cohort ${ }^{22}$ of Schwab et al in which only $2.1 \%$ of the $28.6 \%$ of patients with dyslipidemia were being treated. Interestingly, with the older populations of previous audits, dyslipidemia was more successfully identified and treated, with $22.5 \%-60 \%$ of patients achieving lipid targets. ${ }^{19,20}$

\section{Smoking}

There are a similar proportion of smokers in our audit compared to ANDIAB (Australian National Diabetes Information Audit and Benchmarking) data $(9.8 \%$ versus $9 \%) .{ }^{25}$ However, there appears to be less attention paid to smoking status in our population with $60 \%$ (compared with $12 \%$ in ANDIAB) of patients not having their smoking status documented. This disparity may relate to perceived overall cardiovascular risk, with older patients being at higher risk, at least in the short term, of adverse cardiovascular events and therefore most in need of risk factor modification.

\section{Antiplatelet agents}

Despite the limited data on efficacy of antiplatelet agents in primary prevention of cardiovascular events in diabetes mellitus ${ }^{8,33}$ (particularly in younger patients) and recent evidence in older patients with type 2 diabetes that aspirin may not provide a benefit, ${ }^{34}$ aspirin is still recommended for primary prevention in young patients with diabetes who have additional cardiovascular risk factors. ${ }^{9}$ The percentage of patients who were prescribed antiplatelet therapy in this audit is lower than in previous audits. Twenty-two percent of diabetic patients in the NHANES (National Health and Nutrition Examination Survey) 1999-2000 were regularly taking aspirin, ${ }^{21}$ compared with only $9 \%$ overall in this current audit. This lack of convincing evidence may help explain why few patients have been prescribed antiplatelet therapy in this population. As for lipid-lowering and antihypertensive therapy prescription, lack of patient insight and nonadherence may also mitigate against administration of antiplatelet agents.

\section{Strengths and weaknesses}

We believe that our report adds important information about control of diabetes and vascular risk factors in younger adults with diabetes. It represents a contemporary audit of processes and outcomes in a cohort of patients under specialist care and demonstrates how challenging providing optimal care 
can be in this patient group. Our time-defined cohort from a single specialist center is unlikely to be representative of all young people with diabetes in Australia. In particular, the number of patients with type 2 diabetes in our sample is small. It is likely that these people are largely cared for in primary, nonspecialist practice. Our data do not allow firm conclusions to be drawn regarding causal factors related to intermediate outcomes such as risk factor control and are clearly inadequate to define the prevalence of actual cardiovascular events.

\section{Possible causal factors}

The reasons for our disappointing results are not clear, but many factors are likely to contribute. Anecdotally, young patients may refuse to start or be nonadherent to prescribed lipid-lowering or aspirin therapy. In a nondiabetic population, reasons for nonadherence to statin therapy included young age, smoking, and the patients' lack of perception that lipid-lowering therapy can help prevent cardiovascular events. ${ }^{35}$ Clinically, we note that young patients with diabetes often fail to comprehend the long-term consequences of poor glycemic control. We suspect that these patients will be similarly indifferent with regards to the effectiveness of lipid-lowering in preventing cardiovascular events. Some patients might be reluctant to start another medication that will continue lifelong, particularly if they do not fully appreciate that it may provide some long-term benefit. Potentially, the cost of additional medications may be prohibitive in younger patients, particularly in students or those with only part-time jobs. Psychological factors such as depression and anxiety may also limit patient adherence to therapy. ${ }^{36} \mathrm{Clini}-$ cian factors are likely to play a role. Without evidence of efficacy from long-term prospective trials in young patients, clinicians may be disinclined to commence primary preventative therapy management. Furthermore, physicians may feel that different treatment goals are more important in young patients, including ongoing rapport building and follow-up or glycemic control.

Although previous audits mentioned above have demonstrated poor attainment of cardiovascular risk factor modification targets, our audit has established that even less importance is being placed on these factors in young adults with diabetes. Similarly, less attention appears to be paid to cardiovascular risk factors in young patients with type 1 diabetes compared with those who have type 2 diabetes. There is little or no difference when comparing the screening and appropriate treatment of microvascular complications, but significant differences when comparing the process measures and outcomes of cardiovascular primary prevention. Patients with type 2 diabetes are more likely to have other features of the metabolic syndrome and may be perceived to be at greater long-term risk for cardiovascular events. Similar outcomes are seen in patients younger than 25 compared with those older than 25 years, particularly with regard to primary cardiovascular risk factor modification. The perception that younger patients and those with type 1 diabetes are at lower risk may account for some of the disparity in macrovascular risk factor modification.

\section{Further questions}

There are many unanswered questions in this area that merit further research. Further assessment of treatment targets in a comparably young diabetic cohort could assess whether the trend of apparent lack of attention to macrovascular risk factor modification found in our audit is replicated in other centers. The potential reasons outlined above to explain our results are largely anecdotal and deserve further evaluation. It remains uncertain how much they are contributing, if at all, to the outcomes of our audit. Furthermore, it is not clear whether the factors leading to poor attainment of treatment targets in previous audits with older populations are of equal importance in our population. It is uncertain how these targets may be improved in an older adult population, but some recent data from Varma et $\mathrm{al}^{37}$ have demonstrated better attainment of treatment targets with community-based endocrinology practice in the United States. However, this program involves an intensive follow-up regimen and it is not clear whether the resources are available in Australia to replicate these results and whether the same improvement will be seen in younger adults with diabetes mellitus. Our results do identify a clear evidence practice gap and set the agenda for further detailed epidemiologic and intervention trials.

\section{Conclusion}

A large number of young adult patients with diabetes mellitus do not achieve recognized treatment targets. There appears to be less emphasis placed on macrovascular risk factor targets compared with previous audits in older patients, in patients with type 1 diabetes compared with type 2 diabetes and in patients younger than 25 years. The reasons for these discrepancies remain unclear, but warrant further investigation. 


\section{Author's contributions}

PD contributed to the intellectual planning, study design, data collection, and writing of this article. DM contributed to the intellectual planning, statistical analysis, writing and review of this article.

\section{Disclosure}

The authors report no conflicts of interest in this work.

\section{References}

1. Effect of intensive blood-glucose control with metformin on complications in overweight patients with type 2 diabetes (UKPDS 34). UK Prospective Diabetes Study (UKPDS) Group. Lancet. 1998;352(9131): 854-865.

2. Intensive blood-glucose control with sulphonylureas or insulin compared with conventional treatment and risk of complications in patients with type 2 diabetes (UKPDS 33). UK Prospective Diabetes Study (UKPDS) Group. Lancet. 1998;352(9131):837-853.

3. Nathan DM, Cleary PA, Backlund JY, et al. Intensive diabetes treatment and cardiovascular disease in patients with type 1 diabetes. $N$ Engl J Med. 2005;353(25):2643-2653.

4. Tight blood pressure control and risk of macrovascular and microvascular complications in type 2 diabetes: UKPDS 38. UK Prospective Diabetes Study Group. BMJ. 1998;317(7160):703-713.

5. Hansson L, Zanchetti A, Carruthers SG, et al. Effects of intensive blood-pressure lowering and low-dose aspirin in patients with hypertension: principal results of the Hypertension Optimal Treatment (HOT) randomised trial. HOT Study Group. Lancet. 1998;351(9118) $1755-1762$.

6. Colhoun HM, Betteridge DJ, Durrington PN, et al. Primary prevention of cardiovascular disease with atorvastatin in type 2 diabetes in the Collaborative Atorvastatin Diabetes Study (CARDS): multicentre randomised placebo-controlled trial. Lancet. 2004;364(9435): 685-696.

7. Gaede P, Vedel P, Larsen N, Jensen GV, Parving HH, Pedersen O. Multifactorial intervention and cardiovascular disease in patients with type 2 diabetes. $N$ Engl J Med. 2003;348(5):383-393.

8. Sacco M, Pellegrini F, Roncaglioni MC, Avanzini F, Tognoni G, Nicolucci A. Primary prevention of cardiovascular events with low-dose aspirin and vitamin E in type 2 diabetic patients: results of the Primary Prevention Project (PPP) trial. Diabetes Care. 2003;26(12): 3264-3272.

9. American Diabetes Association. Standards of medical care in diabetes2007. Diabetes Care. 2007;30 Suppl 1:S4-S41.

10. Berenson GS, Srinivasan SR, Bao W, Newman WP 3rd, Tracy RE, Wattigney WA. Association between multiple cardiovascular risk factors and atherosclerosis in children and young adults. The Bogalusa Heart Study. N Engl J Med. 1998;338(23):1650-1656.

11. McGill HC Jr, McMahan CA, Zieske AW, et al. Associations of coronary heart disease risk factors with the intermediate lesion of atherosclerosis in youth. The Pathobiological Determinants of Atherosclerosis in Youth (PDAY) Research Group. Arterioscler Thromb Vasc Biol. 2000;20(8):1998-2004.

12. Wiegman A, Hutten BA, de Groot E, et al. Efficacy and safety of statin therapy in children with familial hypercholesterolemia: a randomized controlled trial. JAMA. 2004;292(3):331-337.

13. McGill HC Jr, McMahan CA, Gidding SS. Preventing heart disease in the 21st century: implications of the Pathobiological Determinants of Atherosclerosis in Youth (PDAY) study. Circulation. 2008;117(9): 1216-1227.

14. Jarvisalo MJ, Putto-Laurila A, Jartti L, et al. Carotid artery intima-media thickness in children with type 1 diabetes. Diabetes. 2002;51(2): 493-498.
15. Krantz JS, Mack WJ, Hodis HN, Liu CR, Liu CH, Kaufman FR. Early onset of subclinical atherosclerosis in young persons with type 1 diabetes. J Pediatr. 2004;145(4):452-457.

16. Morrison JA, Friedman LA, Harlan WR, et al. Development of the metabolic syndrome in black and white adolescent girls: a longitudinal assessment. Pediatrics. 2005;116(5):1178-1182.

17. Anderson S, Komers R. Aliskiren combined with losartan in diabetes and nephropathy. $N$ Engl J Med. 2008;359(10):1069; author reply 1069-1070.

18. Lindner T. Aliskiren combined with losartan in diabetes and nephropathy. N Engl J Med. 2008;359(10):1068-1069; author reply 1069-1070.

19. Beaton SJ, Nag SS, Gunter MJ, Gleeson JM, Sajjan SS, Alexander CM. Adequacy of glycemic, lipid, and blood pressure management for patients with diabetes in a managed care setting. Diabetes Care. 2004;27(3):694-698.

20. Bryant W, Greenfield JR, Chisholm DJ, Campbell LV. Diabetes guidelines: easier to preach than to practise? Med J Aust. 2006;185(6): 305-309.

21. Saydah SH, Fradkin J, Cowie CC. Poor control of risk factors for vascular disease among adults with previously diagnosed diabetes. JAMA. 2004;291(3):335-342.

22. Schwab KO, Doerfer J, Hecker W, et al. Spectrum and prevalence of atherogenic risk factors in 27,358 children, adolescents, and young adults with type 1 diabetes: cross-sectional data from the German diabetes documentation and quality management system (DPV). Diabetes Care. 2006;29(2):218-225.

23. Wan Q, Harris MF, Jayasinghe UW, et al. Quality of diabetes care and coronary heart disease absolute risk in patients with type 2 diabetes mellitus in Australian general practice. Qual Saf Health Care. 2006;15(2):131-135.

24. Yong TY, Phillipov G, Phillips PJ. Management outcomes of patients with type 2 diabetes: targeting the 10-year absolute risk of coronary heart disease. Med J Aust. 2007;186(12):622-624.

25. NADC-ANDIAB (Australian National Diabetes Information Audit and Benchmarking). 2006. Available from: http://www.health.gov.au/ internet/main/publishing.nsf/Content/73C7834F958FF73FCA2572B4 0000B5AC/\$File/andiab06-all.pdf. Accessed 2010 Sep 24.

26. Advance Collaborative Group, http://www.ncbi.nlm.nih.gov/ pubmed?term $=\% 22$ Patel\%20A\%22\%5BAuthor\%5D Patel A, MacMahon $\mathrm{S}$, et al. Intensive blood glucose control and vascular outcomes in patients with type 2 diabetes. $N$ Engl J Med. 2008;358(24): 2560-2572.

27. Duckworth W, Abraira C, Moritz T, et al. Glucose control and vascular complications in veterans with type 2 diabetes. $N$ Engl $J$ Med. 2009;360(2):129-139.

28. Action to Control Cardiovascular Risk in Diabetes Study Group, Gerstein HC, Miller ME, et al. Effects of intensive glucose lowering in type 2 diabetes. $N$ Engl J Med. 2008;358(24):2545-2559.

29. Holman RR, Paul SK, Bethel MA, Matthews DR, Neil HA. 10-year follow-up of intensive glucose control in type 2 diabetes. NEngl J Med. 2008;359(15):1577-1589.

30. Del Prato S. Megatrials in type 2 diabetes. From excitement to frustration? Diabetologia. 2009;52(7):1219-1226.

31. Maahs DM, Kinney GL, Wadwa P, et al. Hypertension prevalence, awareness, treatment, and control in an adult type 1 diabetes population and a comparable general population. Diabetes Care. 2005;28(2): 301-306.

32. Hatunic M, Burns N, Finucane F, Mannion C, Nolan JJ. Contrasting clinical and cardiovascular risk status between early and later onset type 2 diabetes. Diab Vasc Dis Res. 2005;2(2):73-75.

33. McIntyre HD, Marechal DJ, Deby GP, Mathieu AG, HezeeHagelstein MT, Franchimont PP. Immunoreactive somatostatin in the rat ovary. Acta Endocrinologica (Copenh). 1992;126(6):553-558.

34. Ogawa H, Nakayama M, Morimoto T, et al. Low-dose aspirin for primary prevention of atherosclerotic events in patients with type 2 diabetes: a randomized controlled trial. JAMA. 2008;300(18): 2134-2141. 
35. Kiortsis DN, Giral P, Bruckert E, Turpin G. Factors associated with low compliance with lipid-lowering drugs in hyperlipidemic patients. J Clin Pharm Ther. 2000;25(6):445-451.

36. Stewart SM, Rao U, White P. Depression and diabetes in children and adolescents. Curr Opin Pediatr. 2005;17(5):626-631.
37. Varma S, Boyle LL, Varma MR, Piatt GA. Controlling the ABCs of diabetes in clinical practice: a community-based endocrinology practice experience. Diabetes Res Clin Pract. 2008;80(1):89-95.

\section{Publish your work in this journal}

Diabetes, Metabolic Syndrome and Obesity: Targets and Therapy is an international, peer-reviewed open-access journal committed to the rapid publication of the latest laboratory and clinical findings in the fields of diabetes, metabolic syndrome and obesity research. Original research, review, case reports, hypothesis formation, expert opinion and commentaries are all considered for publication. The manuscript management system is completely online and includes a very quick and fair peer-review system, which is all easy to use. Visit http://www. dovepress.com/testimonials.php to read real quotes from published authors.

Submit your manuscript here: http://www.dovepress.com/diabetes-metabolic-syndrome-and-obesity-targets-and-therapy-journal 